\title{
The Effects of Silica and A Nature Polymer on the Size and Properties of Nano-Hydroxyapatite
}

\section{Nano-Hidroksiapatitin Boyut ve Özelliklerine Silika ve Doğal Polimerin Etkisi}

\author{
Research Article
}

Fariba Najafizadeh ${ }^{1}$, Mir Abdullah Seyed Sadjadi ${ }^{*}$, Seyed Jemiladine Fateami ${ }^{2}$, Mahmood Karimi Mobarakeh ${ }^{3}$, Reza Malekpour Afshar ${ }^{4}$

'Department of Inorganic Chemistry, Science and Research Branch, Islamic Azad University, Tehran, Iran. 2Department of Chemistry, Basic Sciences Faculty, Islamic Azad and Shahid Bahonar University, Kerman, Iran. ${ }^{3}$ Department of Trauma and Orthopedic Surgery, Kerman University of Medical Sciences, Kerman, Iran. ${ }^{4}$ Department of Pathology, Medical School, Kerman University of Medical Sciences, Kerman, Iran.

\section{A B S T R AC T}

\begin{abstract}
n this study, we compared the effects of silica and gelatin in nano hydroxyapatite (nHA) composite with pure hydroxyapatite. We have synthesized hydrothermal nHA gelatin template and silica. They (the obtained samples) were investigated by x-ray diffraction (XRD) and Fourier transform infrared spectroscopy (FT-IR). Scanning and transmission electron microscopy (SEM) was used for characterization of particle size and morphology of the samples. The percentage of elements in the prepared composite was determined using energydispersive $x$-ray spectroscopy (EDS). We have identified that the use of gelatin and silica as a coating agent for $\mathrm{nHA}$ contributes to the increase in the size of the particles.
\end{abstract}

\section{Key Words}

Hydroxyapatite, gelatin, silica, nano composite.

\section{ÖZET}

U çalışmada, saf hidroksiapatit ile nano-hidroksiapatit ( $\mathrm{nHA}$ ) kompozit silika ve jelatinin etkileri kıyaslanmıştır. Bidrotermal nHA jelatin kalıp ve silika sentezlenmiştir. Elde edilen bu örnekler x-Işını kırınım (XRD) ve Fourier Transform Infrared Spektroskopisi FT-IR ile incelenmiştir. Örneklerin morfolojisi, partikül boyutu ve karakterizasyonu için taramalı ve geçirimli elektron mikroskobu (SEM) kullanılmıştır. Hazırlanan kompozit malzemedeki element yüzdesi enerji dağılımı X-ışını spekroskopisi kullanılarak belirlenmiştir. nHA için kaplama ajanı olarak kullanılan jelatin ve silikanın partikül boyutunun artmasına katkıda bulunduğu belirlenmiştir.

\section{Anahtar Kelimeler}

Hidroksiapatit, jelatin, silika, nano kompozit.

Article History: Received: Feb 17, 2016; Revised: May 25, 2016; Accepted: Jun 20, 2016; Available Online: Jul 31, 2016.

DOI: $10.15671 /$ HJBC.20164420574

Correspondence to: M.A.S. Sadjadi, Department of Inorganic Chemistry, Science and Research Branch, Islamic Azad University, Tehran, Iran. 


\section{INTRODUCTION}

Synthetically produced calcium phosphate $\int$ ceramics and implants have an important position among other biomaterials, because they are considered almost fully biocompatible with living bodies when replacing the hard bone tissues. Calcium hydroxyapatite $\left(\mathrm{Ca}_{10}\left(\mathrm{PO}_{4}\right)_{6}(\mathrm{OH})_{2}\right.$ $(\mathrm{HA})$ ) and tri-calcium phosphate $\left(\mathrm{Ca}_{3}\left(\mathrm{PO}_{4}\right)_{2}(\mathrm{TCP})\right)$ are currently recognized as ceramic materials that significantly simulate the mineralogical structure of bone [1,2]. Hydroxyapatite due to its excellent biocompatibility, bioactivity and osteoconductivity is widely used in orthopedic, dental, and maxillofacial applications for bone reconstruction. Nanoparticles of hydroxyapatite, which are prepared synthetically, have chemical and structural similarity with nature hydroxyapatite of bones and teeth [2]. Bone or osseous material is a hard connective tissue that forms part of the skeletal system and is comprised of a matrix hardened by deposited calcium phosphate and other minerals. A bone disorder such as osteoporosis is a growing concern in many aging populations and is associated with bone loss and development of bone brittleness and fractures. In the treatment of bone diseases, such as bone tumors and all similar defects, bone substitutes are needed in the repair/replacement of the infected bone tissue and for the treatment of fractures [3]. Hydroxyapatite $\mathrm{Ca}_{10}\left(\mathrm{PO}_{4}\right)_{6}(\mathrm{OH})_{2}$ is one of the major constituents of inorganic components of human hard tissues, bone, teeth and tendon, which is responsible for the stability, harness and function of these organs [4]. Because of the chemical similarity with the biological calcified tissues, all calcium phosphates are remarkably biocompatible and bioactive [5-7]. This property is widely used in medicine for biomaterials that are either entirely made of or coated with calcium phosphate. Clinically, there is a high demand for synthetic bone substitution materials that mimic the chemical composition of natural hard tissue, as autologous bone is available only in limited amounts [8]. By altering the morphology of HA crystals through controlling the orientation of crystal planes, novel properties may be produced [9]. Especially, hexagonal morphology of the HA may find promising application in dental implants, because the human tooth enamel has flattened hexagonal prisms of hydroxyapatite crystals arranged parallel with the organic molecules [1012]. In spite of the large amount of preparation procedures, only a few have been devoted to synthesis of these apatite compounds with controlled morphology [13]. More recently, the Biomaterials group at Cambridge University (Prof Bill Bonfield) has developed a pure HA and silicon substituted (0.8 wt. \%) co-precipitated HA in granular form. These preparations were implanted in the femoral condyle of rabbits for 23 days with good bio-acceptance and new bone formation both on the surfaces and between the granules of both HAp and Si-HA [14-17]. However, Patel et al. [13] showed that there are much more bone and have reported the formation of bonelike HA on organic polymers using a process of nucleation in sodium silicate solution $[18,19]$ with a greater deposition of $\mathrm{HA}$ in relatively high concentrations of silica (above $2.0 \mathrm{M}$ ) suggesting that silicate oligomers such as dimers, trimmers and cyclic tetramers contribute significantly to HA nucleation [20-22]. Therefore, the aim of this study was evaluation effects of silica and a nature polymer on the size and properties of nanohydroxyapatite.

\section{EXPERIMENTAL}

\section{Materials}

Distilled water, gelatin, $\mathrm{CaCl}_{2} 2 \mathrm{H}_{2} \mathrm{O}, \mathrm{Na}_{3} \mathrm{PO}_{4} 12 \mathrm{H}_{2} \mathrm{O}$, buffer $10, \mathrm{Na}_{2} \mathrm{SiO}_{3}$ and all chemicals needed for synthesis of hydroxyapatite were supplied from Merck Company and used without any further purification.

\section{Methods}

\section{The Synthesis of Nano-hydroxyapatite}

For preparation of hydroxyapatite, $80 \mathrm{~mL}$ of the calcium chloride $0.1 \mathrm{M}$ solution was slowly added to $48 \mathrm{~mL}$ sodium phosphate $0.1 \mathrm{M}$, and stirred at the $\mathrm{pH}=10$. The solution was put in the oven with the temperature of $100^{\circ} \mathrm{C}$ for half an hour and then the formed precipitate was filtered and washed with double-distilled water.

The synthesis of nano-hydroxyapatite composite based on gelatin and silica. 
In situ synthesis of hydroxyapatite rods was carried out in the gelatin matrix. For preparation of modified hydroxyapatite, $2.8 \mathrm{~g}$ gelatin was continuously mixed in $70 \mathrm{~mL}$ distilled water by a magnetic stirrer at its maximum speed and heated simultaneously at about $68^{\circ} \mathrm{C}$. After stirring for 2 hours, $80 \mathrm{~mL}$ of the calcium chloride $0.1 \mathrm{M}$ solution was slowly added to the above prepared biopolymer solution. After stirring for 1 hour, $48 \mathrm{~mL}$ sodium phosphate $0.1 \mathrm{M}$ was added drop wisely, and stirred at the $\mathrm{pH}=10$. The solution was put in the oven with the temperature of $100^{\circ} \mathrm{C}$ for half an hour then $30 \mathrm{cc}$ double-distilled water and $7.0 \mathrm{~g} \mathrm{Na}_{2} \mathrm{SiO}_{3}$ in a beaker were poured later in the solution and it was stirred for half an hour at a temperature of $36.5^{\circ} \mathrm{C}$. The samples were incubated for 72 hours at $36.5^{\circ} \mathrm{C}$. Products were filtered and washed with double-distilled water, and were dried at room temperature.

\section{Characterization/Investigation Methods}

The dried products were characterized using FT-IR spectroscopy. FTIR is a technique which is used to obtain an infrared spectrum of absorption or emission of a solid, liquid or gas. An FTIR spectrometer simultaneously collects high spectral resolution data over a wide spectral range.

$X$-ray diffraction (XRD) relies on the dual wave/particle nature of $X$-rays to obtain information about the structure of crystalline materials. A primary use of the technique is the identification and characterization of compounds based on their diffraction pattern. The dominant effect that occurs when an incident beam of monochromatic $X$-rays interacts with a target material is scattering of those $X$-rays from atoms within the target material. In materials with regular structure (i.e. crystalline), the scattered $\mathrm{X}$-rays undergo constructive and destructive interference. This is the process of diffraction. The diffraction of $X$-rays by crystals is described by Bragg's Law, $n(\lambda)=2 d \sin (\theta)$. The directions of possible diffractions depend on the size and shape of the unit cell of the material. The intensities of the diffracted waves depend on the kind and arrangement of atoms in the crystal structure. We have used the X-ray deffractometer model: X'Pert Pro MPD, Manufacturer: PANalytical,
Year: 2009, Angle measuring range: 157 to $0.6 \mathrm{~d}$ degrees. (XRD; Seisert Argon 3003 PTC using nickel-filtered $\mathrm{XD}-3 \mathrm{a} \mathrm{CU} \mathrm{K}$ radiations $(\lambda=0.154$ nm).

In scanning electron microscopy, (SEM) an electron beam is scanned across a sample's surface. When the electrons strike the sample, a variety of signals are generated, and it is the detection of specific signals which produces an image or a sample's elemental composition. The three signals which provide the greatest amount of information in SEM are the secondary electrons, backscattered electrons, and X-rays. Secondary electrons are emitted from the atoms occupying the top surface and produce a readily interpretable image of the surface. The contrast in the image is determined by the sample morphology. A high resolution image can be obtained because of the small diameter of the primary electron beam. Backscattered electrons are primary beam electrons which are 'reflected' from atoms in the solid. The contrast in the image produced is determined by the atomic number of the elements in the sample. The image will therefore show the distribution of different chemical phases in the sample. Because these electrons are emitted from a depth in the sample, the resolution in the image is not as good as for secondary electrons. Interaction of the primary beam with atoms in the sample causes shell transitions which result in the emission of an X-ray. The emitted $X$-ray has an energy characteristic of the parent element. Detection and measurement of the energy permits elemental analysis (Energy Dispersive X-ray Spectroscopy or EDS).

EDS can provide rapid qualitative, or with adequate standards, quantitative analysis of elemental composition with a sampling depth of 1-2 microns. X-rays may also be used to form maps or line profiles, showing the elemental distribution in a sample surface.

\section{RESULTS and DISCUSSION}

\section{Fourier Transform Infrared Spectroscopy}

FT-IR spectra have been shown for HA in Figure 1 and Silica coated HA+Gelatin in Figure 2. The 


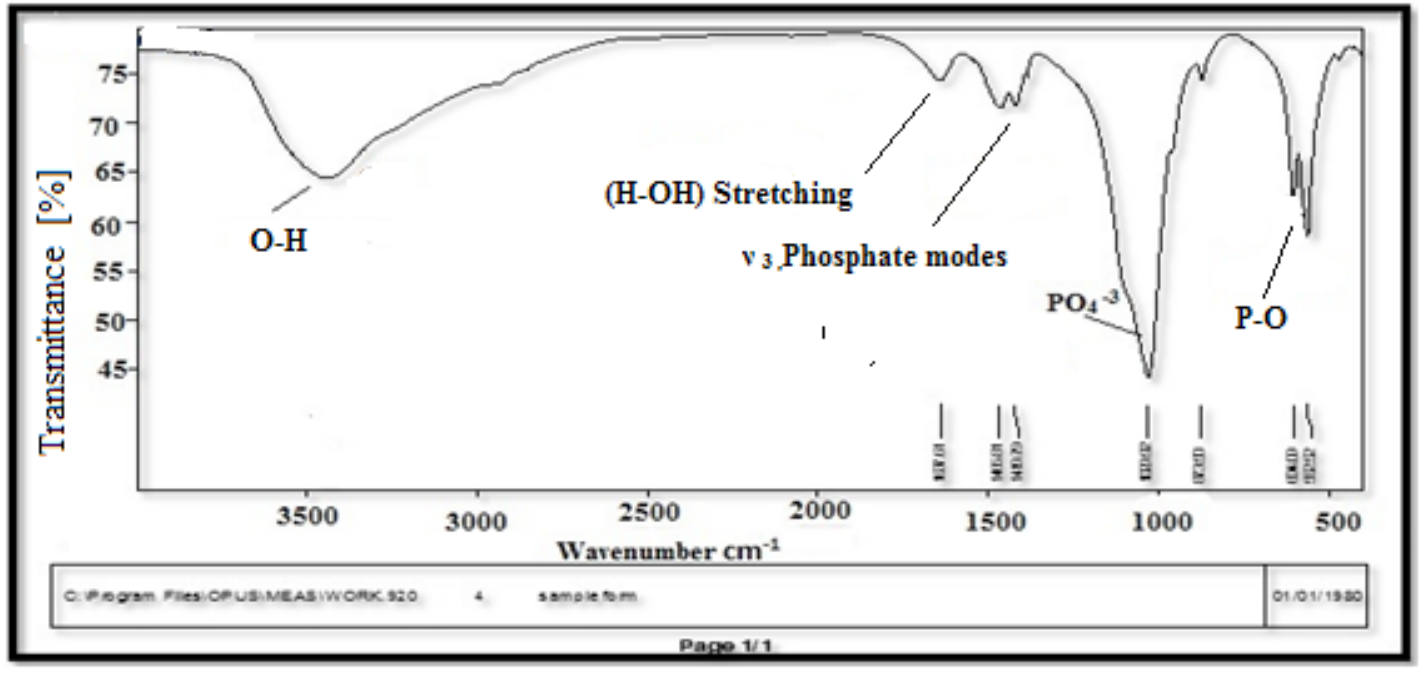

Figure 1. FTIR image of HA.

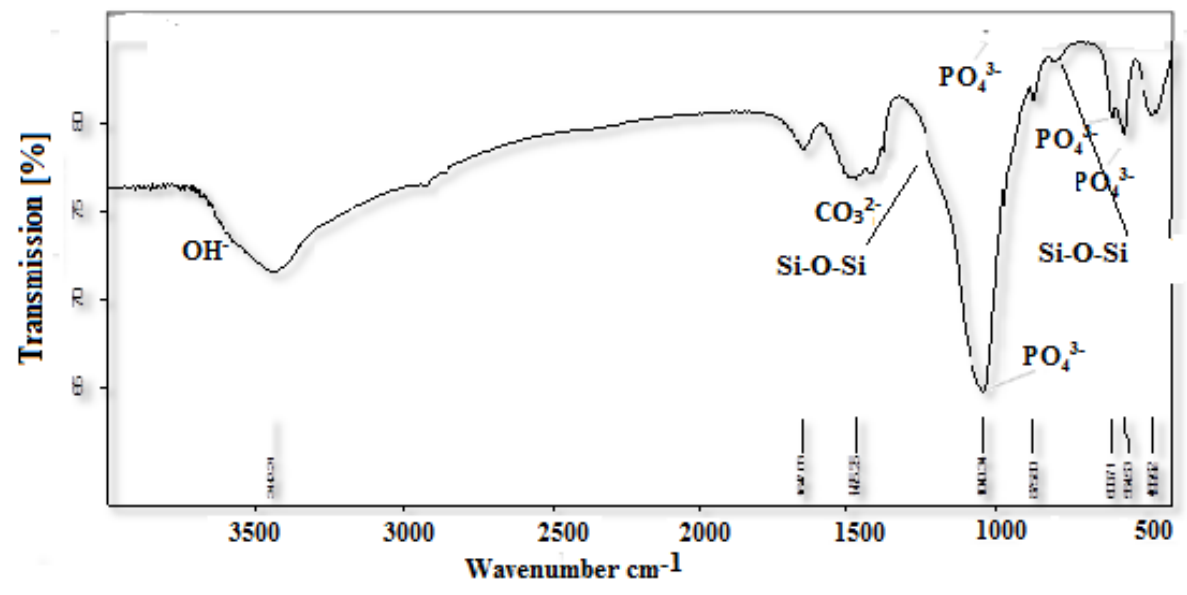

Figure 2. FTIR image of Silica coated (HA+ Gelatin).

peaks of $603.91,563.01,1030.33,1169.81 \mathrm{~cm}^{-1}$ tensile and flexural modes of phosphate groups and the peak of $1611.12 \mathrm{~cm}^{-1}(\mathrm{H}-\mathrm{OH})$ stretching, $3113.76 \mathrm{~cm}^{-1}$ indicates vibration of bond $\mathrm{O}-\mathrm{H}$ confirms the presence of hydroxyapatite. FT-IR spectra for synthesized HA have been shown in Figure 1.

The peaks reported in range of the wavenumber region from $650 \mathrm{~cm}^{-1}$ to $1300 \mathrm{~cm}^{-1}$ for the $\mathrm{SiO}_{2}$. The $\mathrm{Si}-\mathrm{O}$ bond appears at $880 \mathrm{~cm}^{-1}$ and $1250 \mathrm{~cm}^{-1}$ and $\mathrm{Si}-\mathrm{O}$ bond out of plan $485 \mathrm{~cm}^{-1}$ and $\mathrm{Si}-\mathrm{O}$ bonding appears at $800 \mathrm{~cm}^{-1}$, the $\mathrm{Si}-\mathrm{O}-\mathrm{Si}$ bond at $970 \mathrm{~cm}^{-1}, 1083 \mathrm{~cm}^{-1}$ and $1108 \mathrm{~cm}^{-1}$, Si-O bonds at $884 \mathrm{~cm}^{-1}$, the $\mathrm{Si}-\mathrm{OH}$ bond at $880 \mathrm{~cm}^{-1}$ and $939 \mathrm{~cm}^{-1}$, the silica bond of $820 \mathrm{~cm}^{-1}$ [23-27].
FT-IR spectra for synthesized HA in the presence of gelatin and silica have been shown in Figure 2 .

Information FT-IR spectra HA and Silica coated HA+Gelatin have been shown in Tables 1 and 2 , respectively.

The bands at $464,605,566 \mathrm{~cm}^{-1}$ are derived from the 4 phosphate modes. The bands at 1036 $\mathrm{cm}^{-1}$ stand for the Phosphate vibration. The band at $3851 \mathrm{~cm}^{-1}$; band may come from N-H Stretching secondary amid in gelatin, $\mathrm{O}-\mathrm{H}$ Stretching in $\mathrm{HA}$. The stretching vibration and bending modes of the $\mathrm{OH}^{-}$and $(\mathrm{N}-\mathrm{H})$ Stretching amid (II) appeared at $3443 \mathrm{~cm}^{-1}$. The typical peaks of phosphate vibration at $1036 \mathrm{~cm}^{-1}$ and, $\mathrm{C}=0$ stretching at 1651 


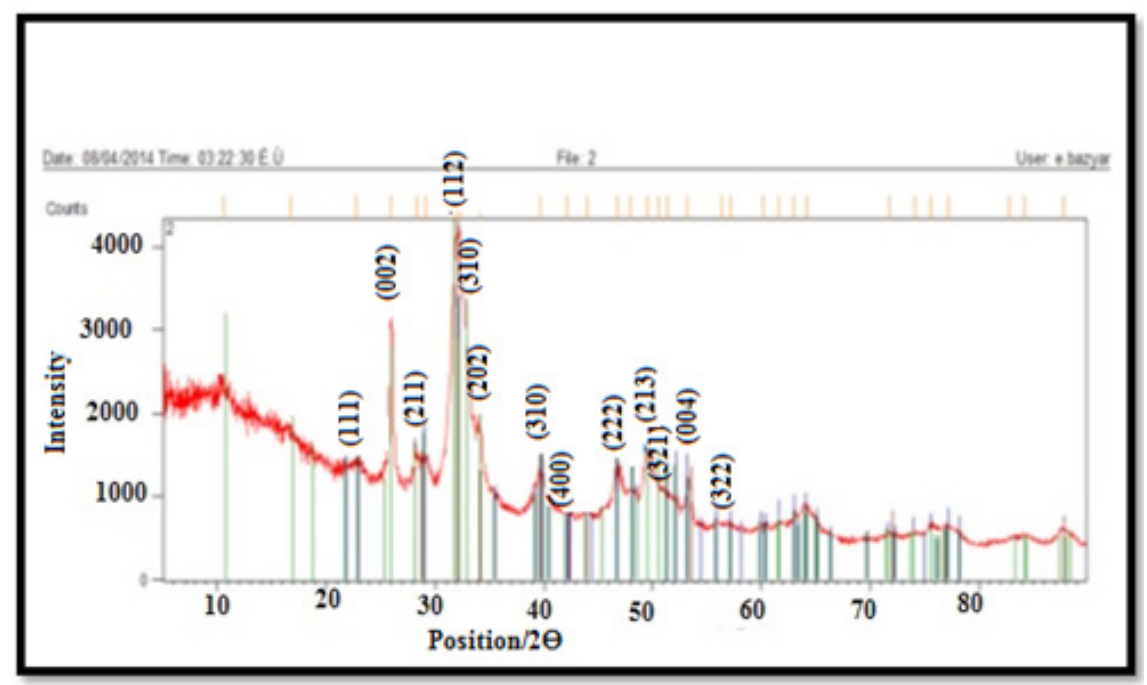

Figure 3. The XRD patterns $\mathrm{nHA}$.

can be seen in spectra. Out-of-plane wagging at $605 \mathrm{~cm}^{-1}$. In FT-IR spectra of HA in the absence of biopolymer, The $464 \mathrm{~cm}^{-1}$ band belongs to the $v$ phosphate mode. The bands at 3413 and 1637 $\mathrm{cm}^{-1}$ correspond to the adsorbed $\mathrm{H}_{2} \mathrm{O}$. Si-O bonds $\left(1100 \mathrm{~cm}^{-1}\right)$ the proof of the silica is coat. The $-\mathrm{NH}$ bending between $1384 \mathrm{~cm}^{-1}$ and $1471 \mathrm{~cm}^{-1}$ can be seen in spectra.

\section{X-ray Diffraction Investigation}

The prepared $\mathrm{nHAs}$ presented diffractions peaks at 2 values of $23,27,31,32,33,34,40,44,47,50$, $52,54,57$ corresponding to (111), (002), (211), (112), (202), (310), (400), (222), (213), (321), (004) and (322) planes, respectively, confirming that the obtained products are predominantly HA (JCPDS \#09-0432). Figure 3 shows the XRD patterns of synthesized $\mathrm{nHA}$.

\section{Investigation the XRD patterns Silica coated $\mathrm{HA}+$ Gelatin}

The peaks of apatite in are widened, indicating that the crystallinity is weak due to the lack of active sites for calcification. It is obvious that the relative intensity of diffraction peaks, particularly the peaks corresponding to (211), (112) and (300) planes are increased when gelatin is added into $\mathrm{nHA}$, implying that the crystallinity of apatite is enhanced, the XRD peaks of as-prepared HA in gelatin solution is similar to that of pure $H A$, implying that gelatin could guide the HA growth with more perfect crystal structure through the interaction between $\mathrm{COO}^{-}$of gelatin and $\mathrm{Ca}^{2+}$ of apatite [28]. The diffraction peaks of the product prepared nHA at 2 values of $22,28,29$, $36,37,38,43$ and 48 corresponding to peaks of silica, (002), (210), (211), (112), (130), (222) and (213) planes, respectively, confirming that the obtained products are predominantly HA (JCPDS \#09-0432). Figure 4 shows the XRD patterns of synthesized Silica coated HA+Gelatin.

\section{Investigation the XRD Patterns Silica Coated $\mathrm{HA}+$ Gelatin}

The peaks of apatite in are widened, indicating that the crystallinity is weak due to the lack of active sites for calcification. It is obvious that the relative intensity of diffraction peaks, particularly the peaks corresponding to (211), (112) and (300) planes are increased when gelatin is added into $n \mathrm{HA}$, implying that the crystallinity of apatite is enhanced, the XRD peaks of as-prepared HA in gelatin solution is similar to that of pure HA, implying that gelatin could guide the HA growth with more perfect crystal structure through the interaction between $\mathrm{COO}^{-}$of gelatin and $\mathrm{Ca}^{2+}$ of apatite [28]. The diffraction peaks of the product prepared $\mathrm{nHA}$ at $2 \theta$ values of $22,28,29,36$, $37,38,43$ and 48 corresponding to peaks of silica, (002), (210), (211), (112), (130), (222) and (213) planes, respectively, confirming that the obtained products are predominantly HA (JCPDS \#09-0432). Figure 4 shows the XRD patterns of synthesized Silica coated HA+Gelatin. 


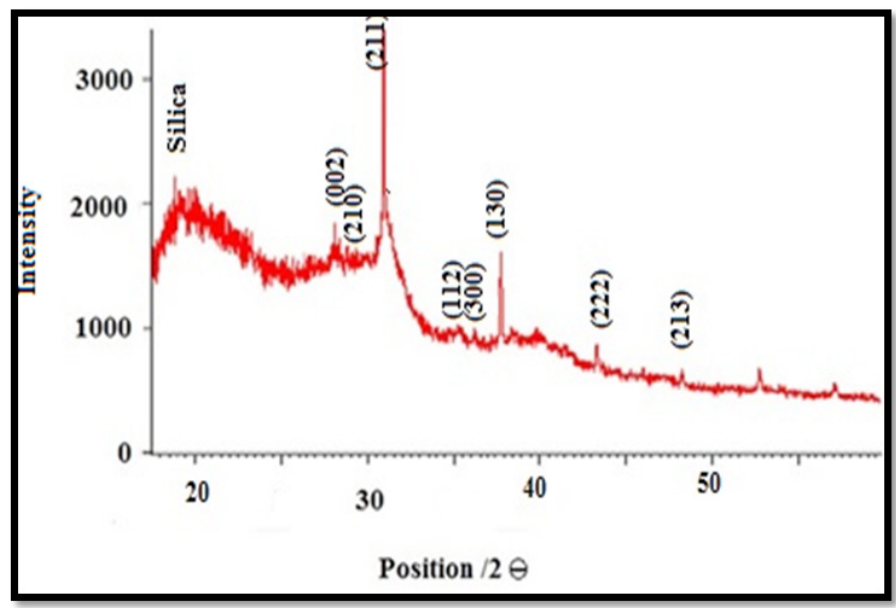

Figure 4. The XRD patterns Silica coated HA+ Gelatin.

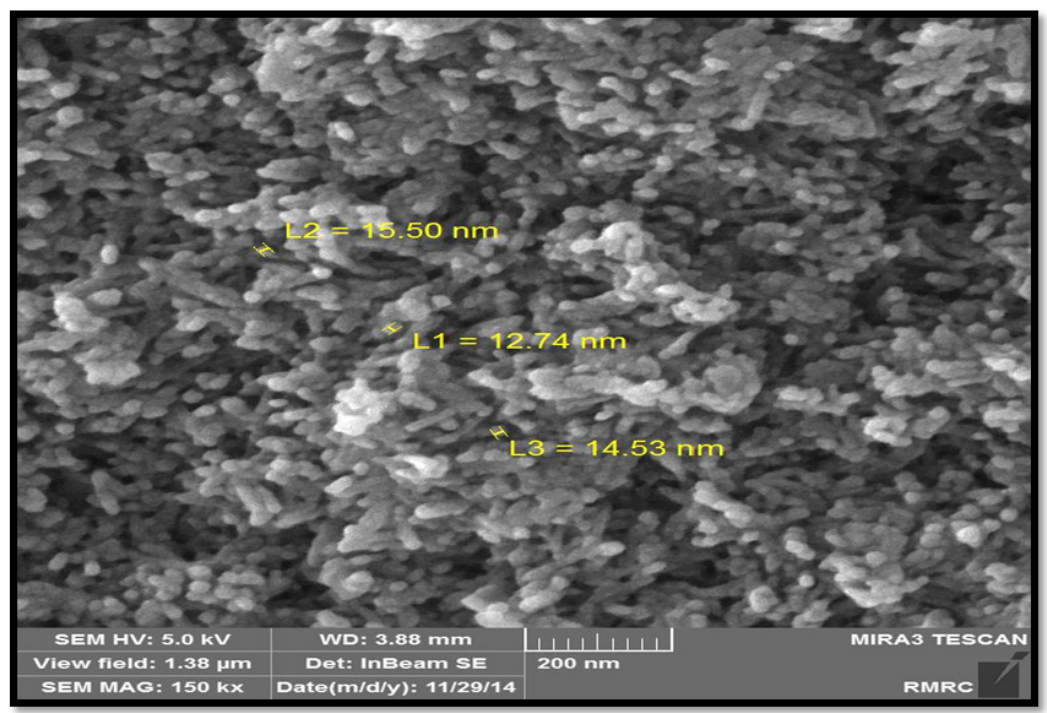

Figure 5. SEM image of nHAp.

Table 3. HA particle size.

\begin{tabular}{cc}
\hline Sample & Particle Size \\
\hline $\mathrm{nHA}$ & $12.75 \mathrm{~nm}$ to $15.5 \mathrm{~nm}$ \\
\hline
\end{tabular}

The results of $\mathrm{X}$-ray spectrum $\mathrm{HA}+$ Gelatin + SiCrystallite size $=10.73 \mathrm{~nm}$ $\mathrm{HA}$ Crystallite size $=6.7 \mathrm{~nm}$

Similar studies indicates that $\mathrm{Si}$ is coat on the $\mathrm{HA}+$ Gelatin and crystallite size $\mathrm{HA}$ is $10.73 \mathrm{~nm}$ and crystallite size HA is $6.7 \mathrm{~nm}$. So existence of $\mathrm{Si}$ is due to greater particles. When silica was as the shell surrounding the hydroxyapatite, crystallite size in XRD patterns Silica coated $\mathrm{HA}+$ Gelatin increases.

\section{Scanning Electron Microscopy SEM Image of $\mathbf{n H A p}$}

SEM spectra for synthesized HA have been shown in Figure 5. The size of particles is ranged from $12.75 \mathrm{~nm}$ to $15.5 \mathrm{~nm}$.

\section{SEM Image of Silica Coated HA+Gelatin}

SEM spectra for synthesized Silica coated HA+ Gelatin have been shown in Figure 6 . The size of particles is ranged from $37.11 \mathrm{~nm}$ to $54.07 \mathrm{~nm}$. Compare the size of the particles formed, proves 


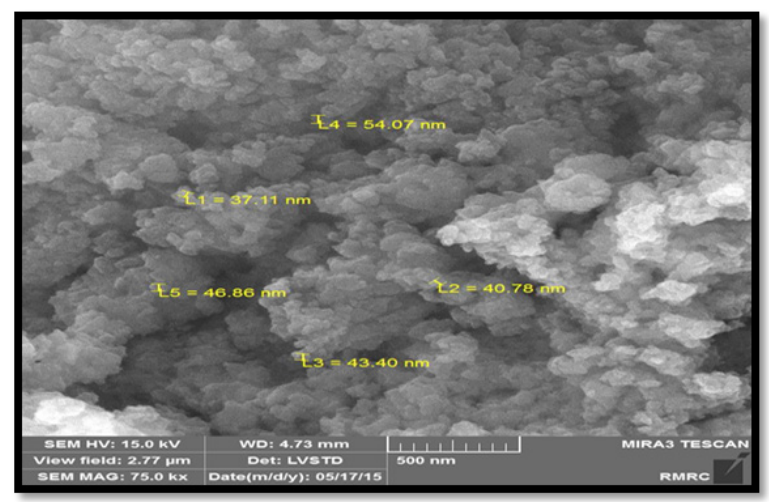

Figure 6. The XRD patterns Silica coated HA+Gelatin.

Table 4. Silica coated HA+Gelatin particle size.

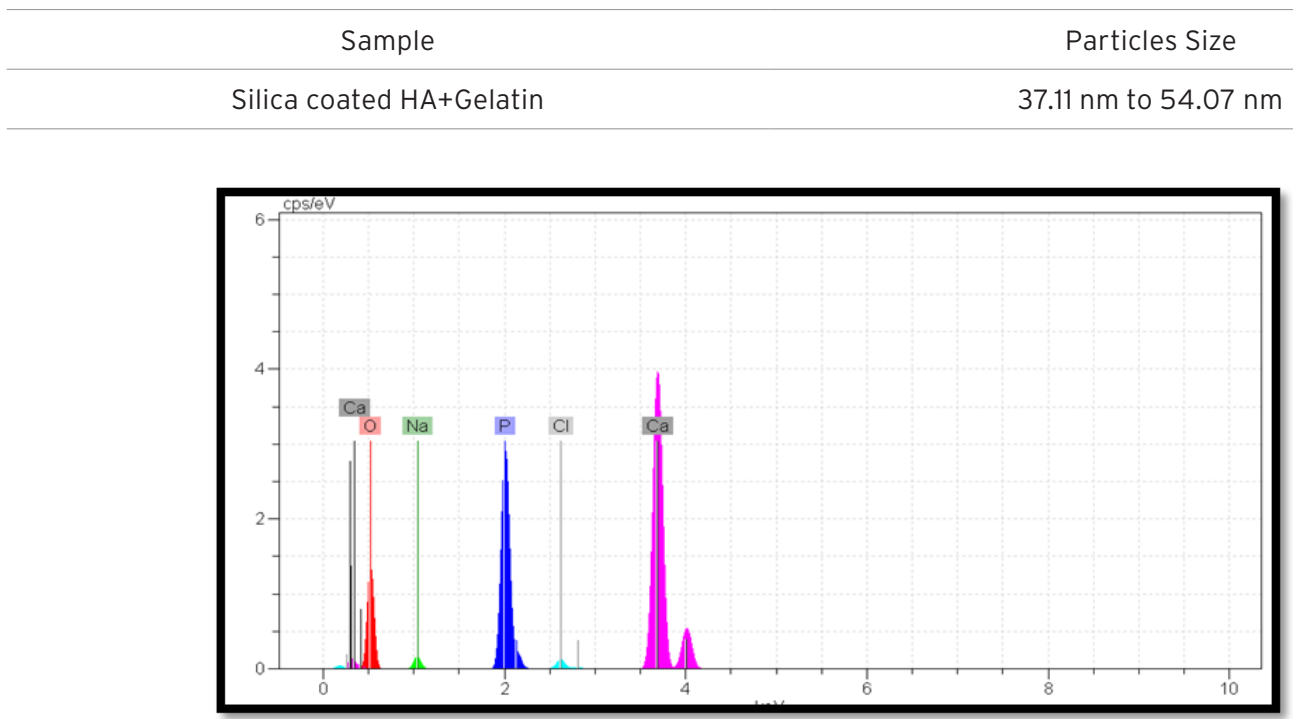

Figure 7. EDS pattern of $\mathrm{nHA}$.

Table 6. EDS quantitative result of HA.

\begin{tabular}{cc}
\hline Element & {$[w t .-\%]$} \\
\hline Oxygen & 31.61 \\
\hline Phosphorus & 25.71 \\
\hline Calcium & 52.68 \\
\hline
\end{tabular}

that, a layer of silica around hydroxyapatite surrounds. Therefore, the size of synthesized nanocomposite particle was greater than pure hydroxyapatite. This observation confirms the core shell.

\section{Energy-dispersive X-ray spectroscopy investigation}

Elemental analysis did by Energy-dispersive X-ray spectroscopy (EDS) method for confirming of nano composite preparation. Figure 7 and Table 5 shows obtain results for synthesized of $\mathrm{HA}$. We obtain the $\mathrm{Ca} / \mathrm{P}$ ratios by using of amount of calcium and phosphorus. The $\mathrm{Ca} / \mathrm{P}$ ratios of 1.7 were calculated for $\mathrm{HA}$ with gelatin, this ratio is nearly to the theoretical value. Considering the repeat unit of the $\mathrm{HA}$ chemical structure $\mathrm{Ca}_{10}\left(\mathrm{PO}_{4}\right)_{6}(\mathrm{OH})_{2}$. In addition, Figure 8 and Table 6 show EDS analysis for HA/ gelatin silica coated. The presence of silica in Figure 8 and Table 6 


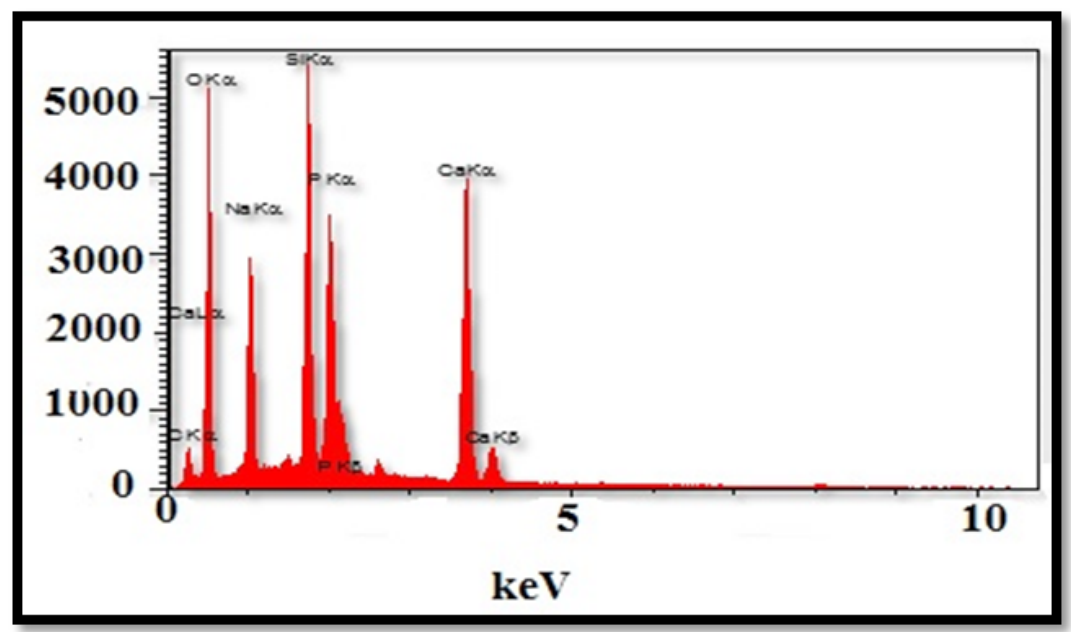

Figure 8. EDS pattern of HA/gelatin coated with silica.

Table 5. EDS quantitative result of $\mathrm{HA}$.

\begin{tabular}{ccc}
\hline Element & {$[$ wt. $\%]$} & {$[$ A. $\%]$} \\
\hline $\mathrm{C}$ & 12.11 & 18.82 \\
\hline $\mathrm{O}$ & 49.38 & 57.62 \\
\hline $\mathrm{Na}$ & 7.69 & 6.69 \\
\hline $\mathrm{Si}$ & 8.36 & 5.55 \\
\hline $\mathrm{P}$ & 8.67 & 4.90 \\
\hline $\mathrm{Ca}$ & 13.79 & 6.42 \\
\hline
\end{tabular}

confirms coated of silica in HA/gelatin matrix. The $\mathrm{Ca} / \mathrm{P}$ ratios of 1.6 were calculated for $\mathrm{HA} /$ gelatin silica coated, this ratio is equivalent to the theoretical value. Considering the repeat unit of the HA chemical structure $\mathrm{Ca}_{10}\left(\mathrm{PO}_{4}\right)_{6}(\mathrm{OH})_{2}$.

\section{CONCLUSIONS}

The presence of $\mathrm{PO}_{4}{ }^{3-}$ group in $\mathrm{nHA}$ and $\mathrm{Si}-\mathrm{HA}$ synthesized in gelatin matrix was confirmed from IR studies.

The absorption band observed at 3425-3586 $\mathrm{cm}^{-1}$ corresponding to the characteristic stretching vibration of the $\mathrm{OH}$ - groups in $\mathrm{HA}$ structure shows the presence of HA structure in both the cases.

The EDAX elemental analysis data and appearance of additional new bands in FTIR spectrum observed at 800 and $1250 \mathrm{~cm}^{-1}$ confirm presence of silica components in Si-HA samples. Appearance of the same atomic ratio of $\mathrm{Ca} / \mathrm{P}$ for the samples before and after immersion in silica solution confirms that any substitution of phosphate by silicate ions has not been occurred in HA samples.

\section{References}

1. K. Nezahat, A. Cuneyt, Synthesis of calcium hydroxyapatite-tricalcium phosphate (HA-TCP), composite bioceramic powders and their sintering behavior. Journal of the American Ceramic Society, 81 (1998) 2245-2252.

2. Y. Zhai, F.Z. Cui, Recombinant human-like collagen directed growth of hydroxyapatite nanocrystals. Journal of Crystal Growth, 291 (2006) 202-206.

3. T. Ddourková, J. Zelenkab, M. Zelenkováb, L. Benes, L. Svoboda, Synthesis of sphere-like nanoparticles of hydroxyapatite. Procedia Engineering, 42 (2012) 1816-1821. 
4. M. Meskinfam, M.S. Sadjadi, H. Jazdarreh, Biomimetic preparation of nano hydroxyapatite in gelatin-starch matrix, World Academy of Science, Engineering and Technology, 76 (2011) 395-398.

5. Y. Liu, D. Hou, G. Wang, A simple wet chemical synthesis and characterization of hydroxyapatite nanorods. Materials Chemistry and Physics, 86 (2004) 69-73.

6. S.V. Dorozhkin, M. Epple, Biological and medical significance of calcium phosphates. Angewandte Chemie International Edition, 41 (2002) 3130-3146.

7. D. Tadic, A. Veresov, V.I. Putlayev, M. Epple, Invitro preparation of nanocrystalline calcium phosphates as bone substitution materials in surgery. Materialwissenschaft und Werkstofftechnik, 34 (2003) 1048-1051.

8. M. Aizawa, A.E. Porter, S.M. Best, W. Bonfield, Ultra structural observation of single-crystal apatite fibres. Biomaterials, 26 (2005) 3427-3433.

9. S. Busch, Regeneration of human tooth enamel, Angewandte Chemie International Edition, 43 (2004) 1428-1431.

10. E.F. Bres, J.L. Hutchison, Surface structure study of biological calcium phosphate apatite crystals from human tooth enamel. Journal of Biomedical Materials Research, 63 (2002) 433-440.

11. J. Liu, X. Ye, H. Wang, M. Zhu, B. Wang, H. Yan, The influence of $\mathrm{pH}$ and temperature on the morphology of hydroxyapatite synthesized by hydrothermal method, Ceramics International, 29 (2003) 629-633.

12. A.M. Pietak, J.W. Reid, M.J. Stott, M. Sayer, Silicon substitution in the calcium phosphate bioceramics, Biomaterials, 28 (2007) 4023-4032.

13. N. Patel, S.M. Best, W. Bonfield, I.R. Gibson, K.A. Hing, E. Damien, P.A. Revell, A comparative study on the in vivo behavior of hydroxyapatite and silicon substituted hydroxyapatite granules. Journal of Materials Science: Materials in Medicine, 13 (2002) 1199-1206.

14. F. Miyaji, H.M. Kim, S. Handa, T. Kokubo, T. Nakamura, Bonelike apatite coating on organic polymers: novel nucleation process using sodium silicate solution, Biomaterials, 20 (1999) 913-919.

15. M.S. Sadjadia, H.R. Ebrahimia, M. Meskinfamb, K. Zarec, Silica enhanced formation of hydroxyapatite nan crystals in simulated body fluid(SBF) at $37^{\circ} \mathrm{C}$, Materials Chemistry and Physics, 13 (2011) 67- 71.

16. M. Meskinfam, M.S. Sadjadi, H. Jazdarreh, In vitro bioactivity behaviour of hydroxyapatite-gelatin nano biocomposites, Journal of Nanostructure in Chemistry, 2 (2011) 1-7.

17. S. Jaya, T.D. Durance, R. Wang, Preparation and physical characterization of gelatin-starch/ hydroxyapatite porous composite scaffold fabricated using novel microwave energy under vacuum technique, Journal of Composite Materials, 43 (2009) 1451-1460.
18. W. Feng, G. Enyan, S. Enmin, Z. Jinhua, Structure and properties of bone-like-nanohydroxyapatite/gelatin/ polyvinyl alcohol composites. Advances in Bioscience and Biotechnology, 1 (2010) 185-189.

19. P. Hui, S.L. Meena, R.D. Gurbhinder Singh, S.P. Sgarawal, Synthesis of hydroxyapatite bio-ceramic powder by hydrothermal method. Journal of Minerals \& Materials Characterization \& Engineering, 9 (2010) 683-692.

20. S. Musi, N. Filipovi-Vincekovi, L. Sekovani, Precipitation of amorphous $\mathrm{SiO} 2$ particles and their properties. Brazilian Journal of Chemical Engineering, 28 (2011) 89-94.

21. M. Manoj, P. Satya, S.K. Nath, K.S. Pawan, Preparation methodology of hydroxyapatite powder: A review. National Conference on Advancements and Futuristic Trends in Mechanical and Materials Engineering, India, (2010) 19-20.

22. M.H. Fathia, A. Hanifi, V. Mortazavi, Preparation and bioactivity evaluation of bone-like. Journal of Materials Processing Technology, 202 (2008)536542.

23. J.A. Rýo, P.J. Morando, D.S. Cicerone, Natural materials for treatment of industrial effluents: comparative study of the retention of $\mathrm{Cd}, \mathrm{Zn}$ and Co by calcite and hydroxyapatite. Part I: batch experiments. Journal of Environmental Management, 71 (2004) 169-177.

24. E.S.Bogya, R. Barabás, L. Bizo, V.R. Dejeu, Preparation and characterization of silicate hydroxyapatites used for copper sorption, Proceedings of the 11th ECERS Conference, Krakow, (2009) 1109-1113.

25. K.C. Chi, Comparison between SiOC thin films fabricated by using plasma enhance chemical vapor deposition and $\mathrm{SiO}_{2}$ thin films by using Fourier transform infrared spectroscopy, Journal of the Korean Physical Society, 56 (2010) 1150-1155.

26. T. Oh, Origin of the $\mathrm{SiCH}_{3}$ peak position shift in $\mathrm{SiOC}$ films, Japanese Journal of Applied Physics, 45 pp. (2006) 264-268.

27. T. Oh, Correlation between potential barrier and FTIR spectra in SiOC film with the $\mathrm{C}-\mathrm{O}$ bond of $\mathrm{sp} 3$ structure, Bulletin of the Korean Chemical Society, 30 (2009) 467-470.

28. D. Yi, Z. Xianghui, Z. Yongsheng, Z. Peizhi, Z. Li, W. Shicheng, In vitro growth of bioactive nanostructured apatites via agar-gelatin hybrid hydrogel. Journal of Biomedical Nanotechnology, 9 (2013) 1972-1983. 
